\title{
On the morphology and molecular basis of segregation of Ceriops zippeliana and C. decandra (Rhizophoraceae) from Asia
}

\author{
C.-R. Sheue ${ }^{1}$, H.-Y. Liu², C.-C. Tsai ${ }^{3}$, S.M.A. Rashid ${ }^{4}$, J.W.H. Yong ${ }^{4}$, Y.-P. Yang ${ }^{2}$
}

\section{Key words}

Ceriops decandra

Ceriops zippeliana

lectotypification

Malesia

mangrove

Rhizophoraceae

trnL intron
Abstract Ceriops zippeliana, a member of the mangrove Rhizophoraceae, was first reported in 1849. It was considered to be a synonym of $C$. decandra, which is still widely accepted. We present morphological and molecular evidence to show that $C$. zippeliana is significantly distinct from $C$. decandra, and illustrations and an identification key to both species.

Published on 30 October 2009

\section{INTRODUCTION}

The mangrove flora of the world consists of around 84 species, 36 genera in 26 families (Saenger 2002). Among the members, the pan-tropical family Rhizophoraceae R.Br. comprising 16 genera and about 120 species of evergreen trees and shrubs (Hou 1958), is the richest mangrove family with four exclusively mangrove genera with 16 species (Saenger 2002). A detailed study of this family showed that an additional mangrove speadded (Sheue 2003).

Ceriops Arn. is one of the mangrove genera of Rhizophoraceae with a widespread geographical range from eastern Africa, nesia and southern China (Hou 1958, Tomlinson 1986, Duke 2006, Hogarth 2007). The species are typically constituents of the inner mangroves, often forming pure stands on better drained sites or becoming stunted in exposed and highly saline sites, within the reach of occasional tides (Hou 1958). Although Ceriops is a small genus with two species recognized by Hou (1958), some 20 names have been synonymized, which gave rise to the likelihood that certain taxonomic features may have been ignored or misapplied as the result of its complicated taxonomic history. Currently three species of Ceriops are widely accepted, namely C. australis, C. decandra and C. tagal (Field 1995, Lin 1999, Saenger 2002, Duke 2006).

In 1999, the first author noticed that the specimens of so-called C. decandra collected from Singapore are morphologically and anatomically different from C. decandra collected in India (Sheue 2003). After five years of field observations and herbarium work, we have come to conclude that the species collected from Singapore should be called C. zippeliana Blume, and that this species had been misapplied since Hou's revision. Besides Singapore, C. zippeliana occurs in other areas of south-eastern Asia as well.

${ }^{1}$ Department of Biological Resources, National Chiayi University, 300 Syuefu Rd., Chiayi 600, Taiwan. Lien-hai Rd., Kaohsiung 804, Taiwan.

${ }^{3}$ Kaohsiung District Agricultural Improvement Station, 2-6 Dehe Rd., Changihih Township, Pingtung County 908, Taiwan.

${ }^{4}$ Natural Sciences \& Science Education, National Institute of Education, 1 Nanyang Walk, Nanyang Technological University, 637616 Singapore. cies could be included and possibly more new taxa may be throughout tropical Asia, northern Australia to Melanesia, Micro-

2 Department of Biological Sciences, National Sun Yat-sen University, 70

\section{MATERIAL AND METHODS}

\section{Morphology and pollen evidence}

Fresh specimens of so-called $C$. decandra were examined from various locations around Singapore and in West Malaysia; herbarium specimens were studied from BM, BO, CAL, CHIA, DNA, GH, IBSC, K, L, MO, SING and TAI.

Pollen grains were smeared on the surface of a slide and examined with an Olympus $\mathrm{BH}-2$ light microscope to measure the size $(n=30)$. For scanning electron microscopy pollen grains were air dried and scattered on the surface of a stub covered with double-side tape, coated with gold and examined with a Hitachi S-2400 scanning electron microscope.

\section{Molecular evidence}

Populations of so-called C. decandra were sampled at three sites in India and Singapore during 2003 to 2005 (Table 1). Voucher specimens were deposited in the Herbarium of $\mathrm{Na}$ tional Chiayi University (CHIA). The accession numbers of the sequences from both $C$. decandra and $C$. zippeliana plus two outgroup accessions are shown in Table 1.

Table 1 A list of the molecular study for the seven accessions of Ceriops decandra and the seven accessions of $C$. zippeliana, as well as the two outgroups, and their different geographical distributions.

\begin{tabular}{llll}
\hline No. & Taxon & Collection location & $\begin{array}{l}\text { Accession } \\
\text { no. }\end{array}$ \\
\hline Rh-26 & C. decandra & Pichavarum, India & EF118952 \\
Rh-28 & C. decandra & West Sundarbans, India & EF118953 \\
Rh-29 & C. decandra & West Sundarbans, India & EF118954 \\
Rh-30 & C. decandra & West Sundarbans, India & EF118955 \\
Rh-34 & C. decandra & West Sundarbans, India & EF118956 \\
Rh-35 & C. decandra & West Sundarbans, India & EF118957 \\
Rh-36 & C. decandra & West Sundarbans, India & EF118958 \\
Rh-43 & C. zippeliana & Pasir Ris Nature Park, Singapore & EF118973 \\
Rh-44 & C. zippeliana & Pasir Ris Nature Park, Singapore & EF118974 \\
Rh-45 & C. zippeliana & Pasir Ris Nature Park, Singapore & EF118975 \\
Rh-46 & C. zippeliana & Pasir Ris Nature Park, Singapore & EF118976 \\
Rh-54 & C. zippeliana & Pasir Ris Nature Park, Singapore & EF118979 \\
Rh-56 & C. zippeliana & Pasir Ris Nature Park, Singapore & EF118982 \\
Rh-57 & C. zippeliana & Pasir Ris Nature Park, Singapore & EF118983 \\
Rh-31 & C. tagal & West Sundarbans, India & EF118987 \\
Rh-73 & C. australis & Darwin, Australia & EF118951 \\
\hline
\end{tabular}

(c) 2009 Nationaal Herbarium Nederland

You are free to share - to copy, distribute and transmit the work, under the following conditions:

Attribution: $\quad$ You must attribute the work in the manner specified by the author or licensor (but not in any way that suggests that they endorse you or your use of the work).

Non-commercial: You may not use this work for commercial purposes.

No derivative works: You may not alter, transform, or build upon this work

For any reuse or distribution, you must make clear to others the license terms of this work, which can be found at http://creativecommons.org/licenses/by-nc-nd/3.0/legalcode. Any of the above conditions can be waived if you get permission from the copyright holder. Nothing in this license impairs or restricts the author's moral rights. 


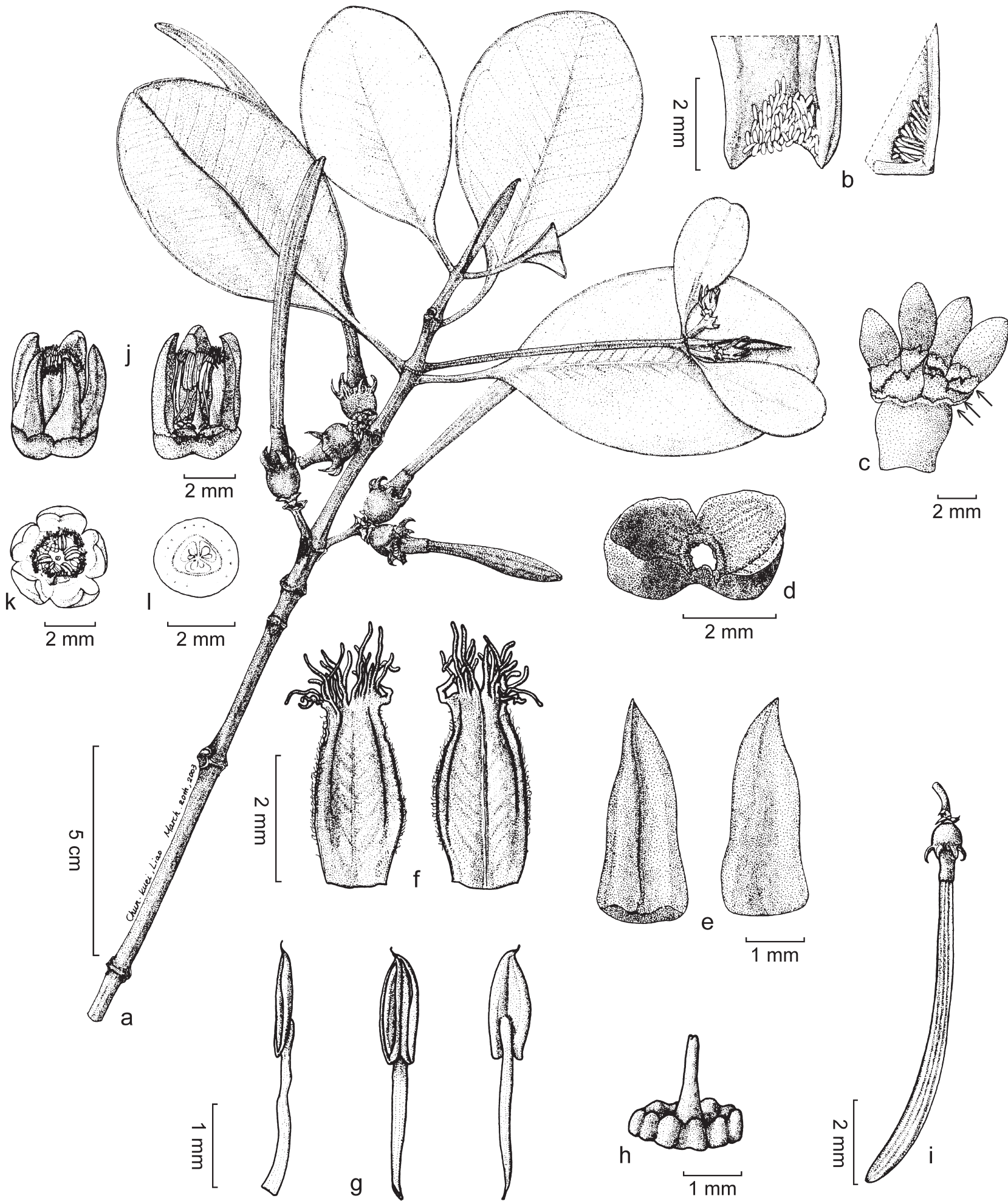

Fig. 1 Ceriops decandra (Griff.) Ding Hou. a. Fruiting shoot; b. stipule with colleters at adaxial base, one in lateral view with some tissue removed; c. inflorescence, note the multilayered bracts (arrows); d. bracteole; e. sepals of adaxial (left) and abaxial (right) views; f. petals of adaxial (left) and abaxial (right) views; g. stamens; h. style and nectaries with stamens removed; i. mature detached seedling; j. flowers; k. flower from above; I. cross section of ovary.

Total DNA was extracted using the CTAB method (Doyle \& Doyle 1987) and the trnL intron of chloroplast DNA was amplified using universal primers (Taberlet et al.1991), following the protocols of Tsai et al. (2006). The DNA was sequenced following the method of dideoxy chain-termination using an ABI377 automated sequencer with the Ready Reaction Kit (PE Biosystems, California) of the BigDye ${ }^{\mathrm{TM}}$ Terminator Cycle Sequencing.
DNA sequence alignment was conducted using Clustal W in BioEdit (Hall 1999). Genetic relationships were determined using MEGA v2.1 (Kumar et al. 2001). A genetic distance matrix was calculated using the two-parameter model of Kimura (1980), and then used to construct the phylogenetic trees using the Neighbor-joining (NJ) method (Saitou \& Nei 1987). Bootstrapping (1000 replicates) was carried out to estimate the support for the topology (Felsenstein 1985, Hillis \& Bull 1993). All characters were equally weighted. 

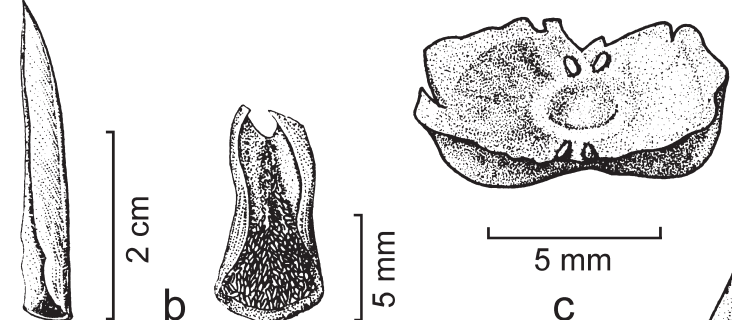

$\frac{E}{\varepsilon}$

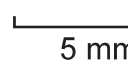

C

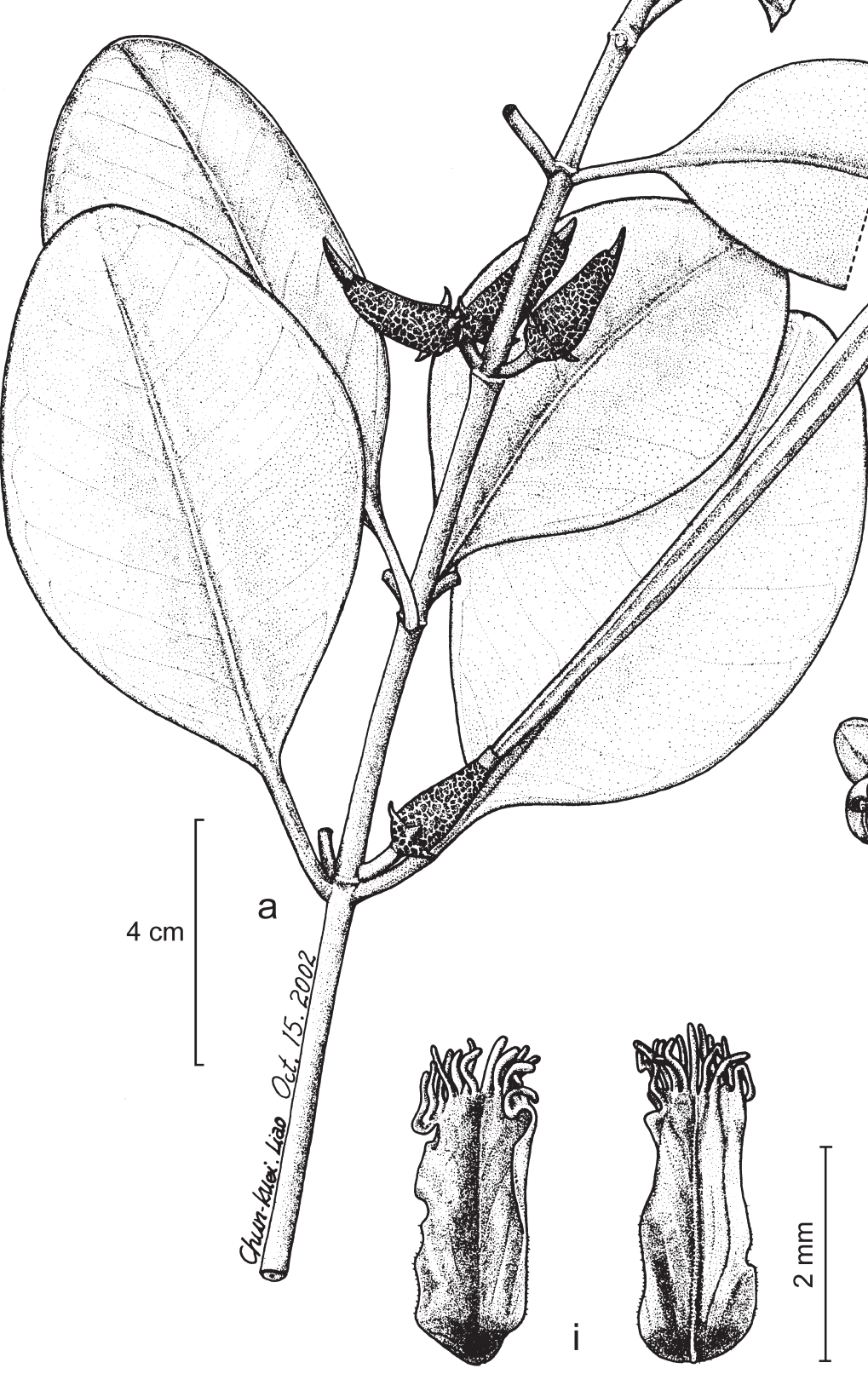

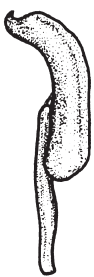
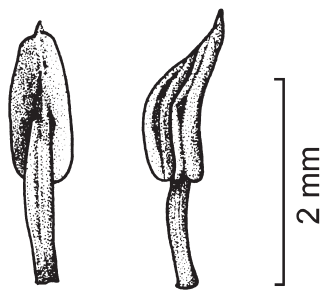

d

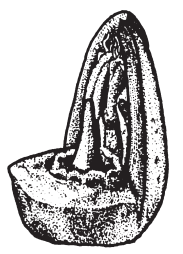

e
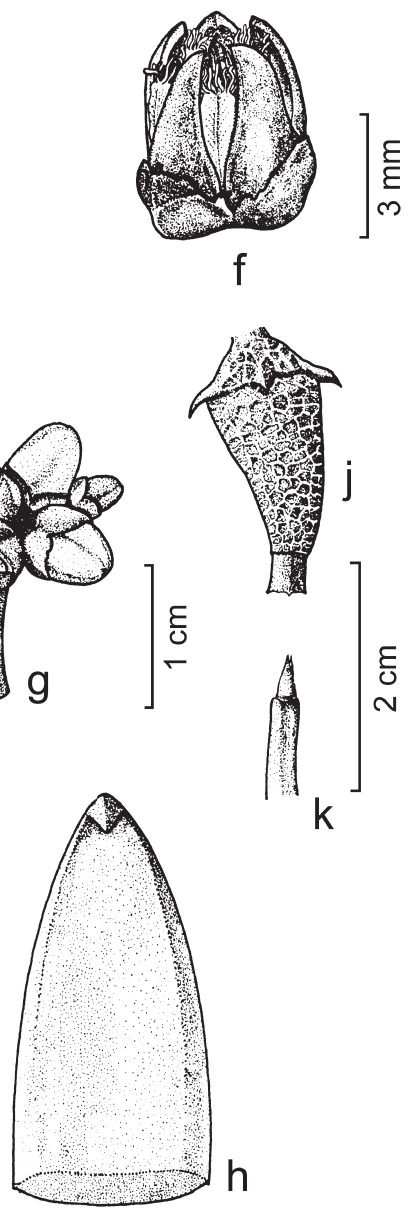

\section{h}

Fig. 2 Ceriops zippeliana Blume. a. Fruiting shoot; b. stipule with colleters at adaxial base; c. top view of bracteole with four colleters; d. stamens; e, f. flower lateral views, the top one showing style with perianth and stamens removed; g. inflorescence; h. sepal of adaxial side; i. petals of adaxial (left) and abaxial (right) views; j. fruit with persistent calyx tube, calyx lobes and cotyledon collar; k. tip of hypocotyl with plumule.

\section{TAXONOMIC TREATMENT}

\section{Key to Ceriops zippeliana and C. decandra}

1. Inflorescence dense bifurcate cyme-like with multilayered bracts enclosing 6-10 flowers; calyx lobe partially patent without an apex reflex while flowering; petal lateral margin densely hairy; persistent calyx tube longer and dome-like; hypocotyl equally thick throughout, with a blunt apex; stipule with 7-8-layered colleters at adaxial base; leaves thickly leathery with 8-10 pairs of lateral veins ... . C. decandra
1. Inflorescence simple head-like with a single layered bracts enclosing 3-6 flowers; calyx lobe closely erect with an apex reflex towards floral axis while flowering; petal lateral margin hairless; persistent calyx tube short and disc-like; hypocotyl unequally thick, tapering towards an acute apex; stipule with 18-20-layered colleters at adaxial base; leaves leathery with 11-12 pairs of lateral veins ............ . zippeliana 

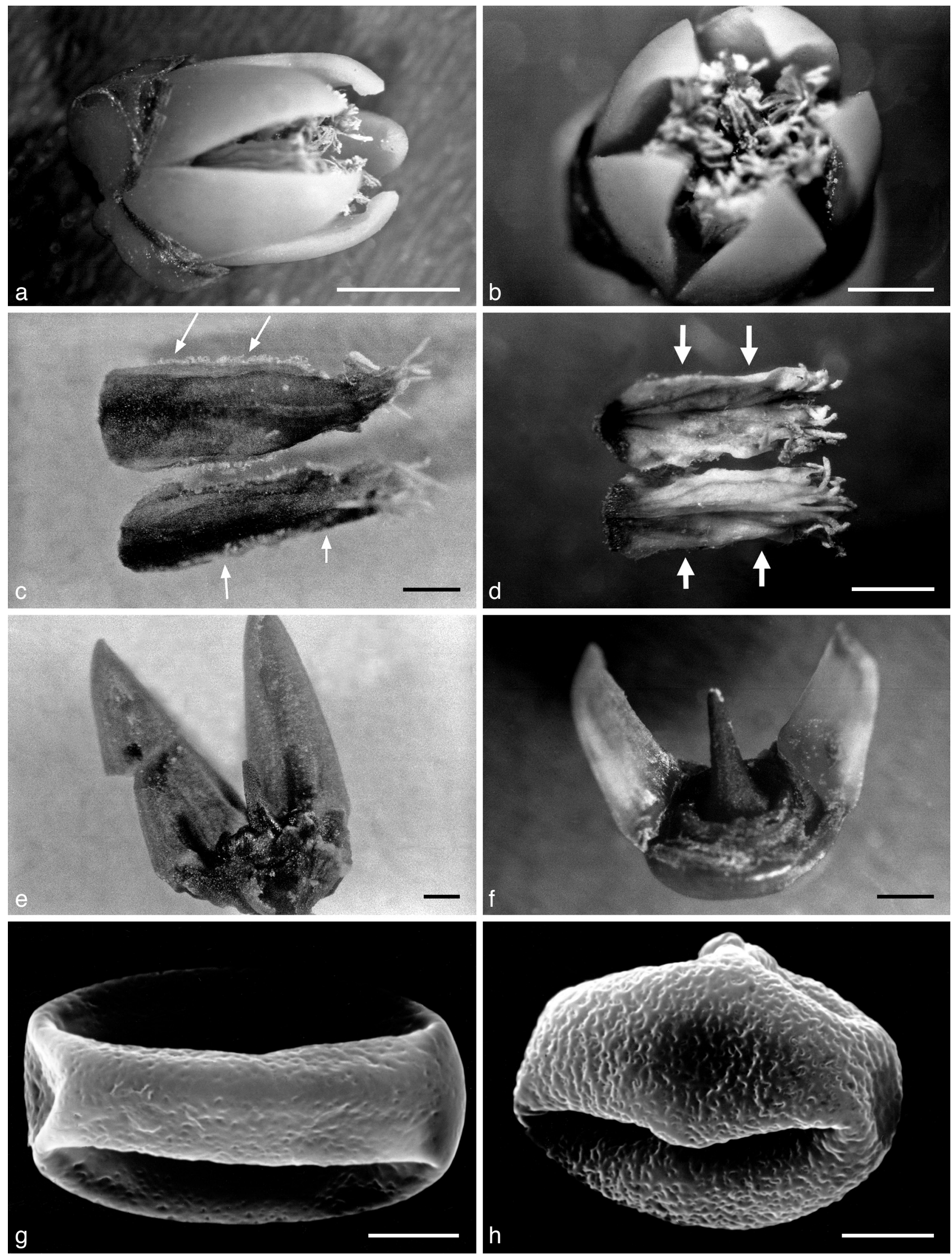

Fig. 3 Floral characters of Ceriops decandra and C. zippeliana. a, b. Floral lateral and top views of C. zippeliana; c. petals of C. decandra: relatively longer terminal cilia at the apex and dense hairs along margins (arrows); d. petals of $C$. zippeliana: relatively shorter terminal cilia at the apex and hairless along margins (bold arrows); e. lateral view of sepals and style of $C$. decandra; f. lateral view of sepals and style of $C$. zippeliana; g. equatorial view of pollen grain of $C$. decandra, with scabrate surface; h. equatorial view of pollen grain of $C$. zippeliana, with regulate surface. - Scale bars: $a-d=1 \mathrm{~mm} ; e, f=2 \mathrm{~mm}$; $\mathrm{g}, \mathrm{h}=5 \mu \mathrm{m}(\mathrm{d}, \mathrm{e}, \mathrm{f}, \mathrm{g}$ from Sheue 2003). 


\section{SPECIES TREATMENTS}

Ceriops decandra (Griff.) Ding Hou — Fig. 1, 3, 4, 7; Table 2

Ceriops decandra (Griff.) Ding Hou (1958) 471, p.p. \& excl. syn. C. zippeliana Blume.

Bruguiera decandra Griff. (1835) 10.

Ceriops roxburgiana Arn. (1838) 364, p.p.

Rhizophora decandra Roxb. (1814) 36, nom. nud

Main diagnostic characters are listed in Table 2.

Distribution - India, Bangladesh, through Myanmar to eastern Thailand.

\section{Ceriops zippeliana Blume - Fig. 2-4, 7; Table 2}

Ceriops zippeliana Blume (1849) 143. - Lectotype (here designated): A. Zippelius 99a (hololecto K; isolecto U), Indonesia, Netherlands New Guinea. See Discussion in the Typification section.

Ceriops decandra auct. non (Griff.) Ding Hou (1958) 471, p.p.

Main diagnostic characters are listed in Table 2.

Distribution - West coast of southern Malay Peninsula, Singapore, Bintan Island, east coast of the Malay Peninsula to the Gulf of Thailand to Vietnam, Borneo, Java, Philippines, Sulawesi, Lesser Sunda Islands, Moluccas (Ceram).

Typification - Blume (1849) did not cite any specimens for his new species $C$. zippeliana. Type specimens were designated by Hou (1958) as he revised the Rhizophoraceae for the Flora of Malesiana. The type specimens have four sheets collected by Zippelius from 'Nov. Guinea' (currently Moluccas and Irian Jaya) and these were deposited at $L$ ( 2 sheets, one with the collection number '99/a' indicated as 'Type!', while the other one without collection number labelled as 'Type Dupl.'), K ('99/a' without label) and U ('99.a' labelled as 'Type Dupl.'), separately. However, it is apparent that two species have been included. The two type specimens at $L$ are characterized by leaves which are elliptic-oblong in shape and fruit with a domelike calyx tube. These characters are obviously different from those of the other two type specimens at $\mathrm{K}$ and $\mathrm{U}$, which have oval to elliptical-oval leaves and a shallow disc-like calyx tube. Blume's original descriptions of "foliis obovatis v. obovalibus" and "pedunculis brevissimis paucifloris" match the characters of the latter specimens as well as our recently collected specimens, and we therefore select the specimens at $\mathrm{K}$ and $\mathrm{U}$ as the lectotype and isolectotype of $C$. zippeliana.

A detailed comparison of the two species is provided in Table 2.

\section{MOLECULAR EVIDENCE}

Alignment of the sequences resulted in 606 characters of which 13 were variable and parsimony informative. No sequence variation was found within $C$. decandra. However, there are three haplotypes in C. zippeliana. The average genetic distance between $C$. decandra and $C$. zippeliana was 0.0039 using the two-parameter method of Kimura (1980). Inspection of the sequence alignment showed three stable insertions/deletions (indels) (i.e., sites 146-179, 267-278
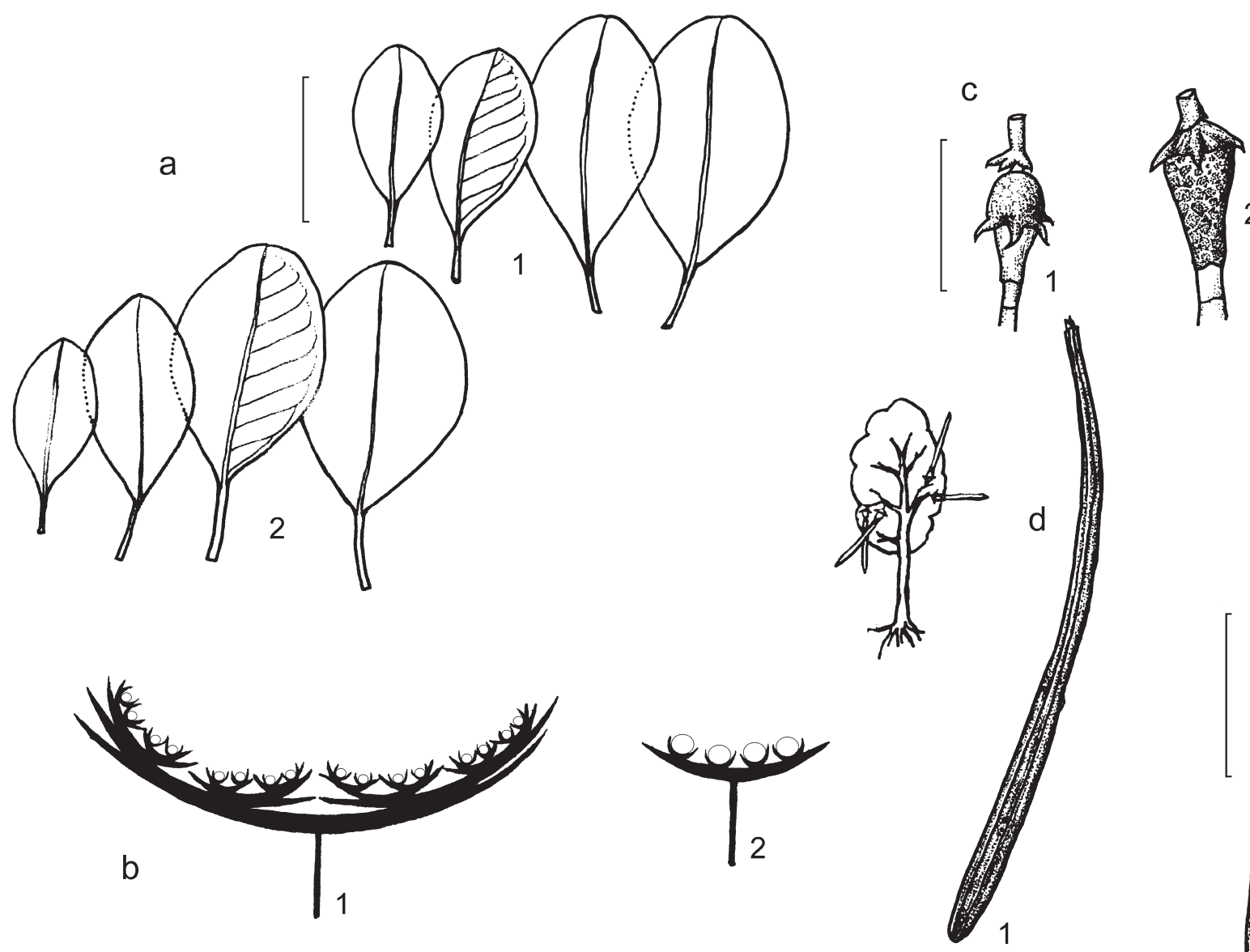

Fig. 4 A comparison of leaves, inflorescences and fruits between Ceriops decandra (1) and C. zippeliana (2) (modified from Sheue 2003). a. Leaves, oval to obovate leaves of $C$. decandra; oval to elliptical-oval leaves of $C$. zippeliana; b. inflorescence, dense bifurcate cymelike with multilayered (primary to fourth) bracts of $C$. decandra; simple head-like with a single layered (primary) bract of $C$. zippeliana; c. fruits, calyx tube domed with longer ascending calyx lobes of $C$. decandra; calyx tube shallow disc-like with short and erect calyx lobes of C. zippeliana; d. hypocotyls and their orientations; hypocotyl width approximately the same tapering towards a blunt apex of $C$. decandra; hypocotyl width unequal thick, tappering towards an acute apex in $C$. zippeliana; the orientations of hypocotyl for these two taxa ranging from lifted to pendent as the diagram shows. 
1111111111111111111111111111111111111222222222222222333333333344444444445555 4444445555555555666666666677777777778466677777777799000222223501111222155579 $45 \underline{67890123456789012345678901234567890778901234567889478567890060123456212364}$
C. decandra-Rh-26
C. decandra-Rh-28
C. decandra-Rh-29
C. decandra-Rh-30
C. decandra-Rh-34
C. decandra-Rh-35
C. decandra-Rh-36
C. zippeliana-Rh-43
C. zippeliana-Rh-44
C. zippeliana-Rh-45
C. zippeliana-Rh-46
C. zippeliana-Rh-54
C. zippeliana-Rh-56
C. zippeliana-Rh-57
C. tagal-Rh-31
C. australis-Rh-73

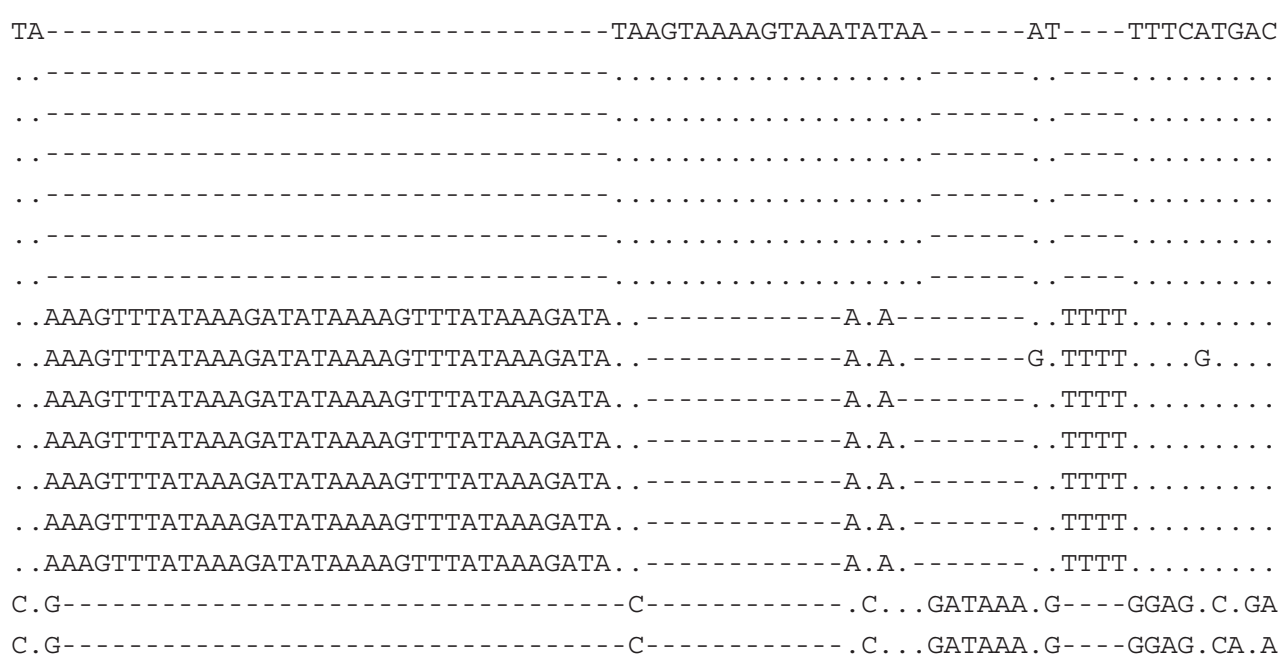

Fig. 5 The variable sites of the $t r n \mathrm{~L}$ intron. Three insertions/deletions are underlined in the site number between Ceriops decandra and C. zippeliana.

Table 2 Comparison between Ceriops decandra (Griff.) Ding Hou and C. zippeliana Blume.

\begin{tabular}{|c|c|c|}
\hline Character & Ceriops decandra & Ceriops zippeliana \\
\hline Habitat & Shrub, 2-5 m high & Small tree, up to $12 \mathrm{~m}$ high \\
\hline Stipule & $\begin{array}{l}1.2-2.4 \mathrm{~cm} \text { before dropping, colleters at adaxial base } \\
50-70(7-8 \text { layered })\end{array}$ & $\begin{array}{l}2.5-3.6 \mathrm{~cm} \text { before dropping, colleters at adaxial base } \\
154-190(18-20 \text { layered })\end{array}$ \\
\hline Leaf & $\begin{array}{l}\text { Oval to obovate, } 4-9 \text { by } 2.5-6 \mathrm{~cm} \text {, lateral veins } 8-10(-11) \text {, } \\
\text { petiole } 1.2-1.8 \mathrm{~cm} \text { in length }\end{array}$ & $\begin{array}{l}\text { Oval to elliptical-oval, } 5.5-11 \text { by } 3-7.5 \mathrm{~cm} \text {, lateral veins } \\
(9-) 11-12(-13) \text {, petiole } 1.5-2.6 \mathrm{~cm} \text { in length }\end{array}$ \\
\hline Inflorescence & $\begin{array}{l}16 \text { buds, }(4-) 6-10(-12) \text { maturing to flowers, dense } \\
\text { bifurcate cyme-like, with multilayered (primary to fourth) bracts }\end{array}$ & $\begin{array}{l}3-5(-7) \text { flowered, simple head-like, only with a single layered } \\
\text { of (primary) bracts }\end{array}$ \\
\hline Bracteole & 2-lobed, 1-2 mm long, with 0-3 colleters inside & 2-lobed, $2.6 \mathrm{~mm}$ in long, with $2-8$ colleters inside \\
\hline Calyx & 4 by $2 \mathrm{~mm}$ & $2-3$ by $2 \mathrm{~mm}$ \\
\hline Corolla & $\begin{array}{l}5,4 \text { by } 1.8-2.0 \mathrm{~mm} \text { (including terminal cilia), with slightly curved } \\
\text { hairs densely along lateral margin, apex with } 20-25 \text { cilia, } \\
0.8-1.25 \mathrm{~mm} \text { long }\end{array}$ & $\begin{array}{l}5,3.0-3.5 \text { by } 1.8 \mathrm{~mm} \text { (including terminal cilia), hairless at the } \\
\text { marginal base, apex with } 13-17 \text { cilia, } 0.5-0.8 \mathrm{~mm} \text { long }\end{array}$ \\
\hline Stamen & $\begin{array}{l}\text { filament } 1.6-2.0 \mathrm{~mm} \text { long, anther } 1.0-1.2 \mathrm{~mm} \text { long, with } \\
\text { one long connective protrusion }\end{array}$ & $\begin{array}{l}\text { filament } 1.0 \mathrm{~mm} \text { long, anther } 1.0 \mathrm{~mm} \text { long, with one short connective } \\
\text { protrusion }\end{array}$ \\
\hline Style & $2.5-3.0 \mathrm{~mm}$ long & $2.0-2.2 \mathrm{~mm}$ long \\
\hline Pollen & $\mathrm{L}=21.0 \pm 1.49 \mathrm{~mm}$ in equatorial view, scabrate surface & $\mathrm{L}=15.43 \pm 1.16 \mathrm{~mm}$ in equatorial view, regulate surface \\
\hline Fruit & $\begin{array}{l}\text { calyx tube domed, } 5 \mathrm{~mm} \text { high, persistent lobes } 4 \text { by } 1.6-2.0 \mathrm{~mm} \text {; } \\
\text { fruit ovoid, } 0.8 \text { by } 0.5-0.6 \mathrm{~cm} \text {, no special decoration }\end{array}$ & $\begin{array}{l}\text { calyx tube shallow disc-shaped, } 3 \mathrm{~mm} \text { high, persistent lobes } 2-2.5 \text { by } \\
1-1.5 \mathrm{~mm} \text {; fruit ovoid-conical, } 1.2-1.5 \text { by } 1.0 \mathrm{~cm} \text {, with netted fissures }\end{array}$ \\
\hline Hypocotyl & $\begin{array}{l}8-13 \text { by } 0.5-0.7 \mathrm{~cm} \text {, ridged and sulcate, width approximately } \\
\text { the same, tapering to a blunt apex }\end{array}$ & $\begin{array}{l}9-17 \text { by } 0.7-0.8 \mathrm{~cm} \text {, ridged and sulcate, width unequal, with a sharp } \\
\text { apex }\end{array}$ \\
\hline
\end{tabular}

and 410-413) and two stable transversions $(A \leftrightarrow T)$ (i.e., sites 298 and 304) within this DNA region between C. decandra and C. zippeliana (Fig. 5).

The phylogenetic tree is shown in Fig. 6, with bootstrap values over $50 \%$ indicated. In this tree, accessions of $C$. zippeliana are separated from all those of $C$. decandra in a clade supported by $88 \%$ bootstrap value. Thus, the molecular data provide further evidence that $C$. zippeliana is distinct from $C$. decandra.

\section{DISCUSSION}

Reproductive characteristics would be useful tools to separate these two morphologically similar species of the genus Ceriops. In the past, most taxonomists had focused on the fringe-like apex of the petals, but not on the marginal hairs of $C$. decan- dra petals (Griffith 1835, Arnott 1838, Hou 1958, Tomlinson 1986, Banerjee et al. 1989, Naskar \& Mandal 1999). Although this character is depicted in Roxburgh's drawing (Rhizophora decandra, Roxb. Icon. Ind. 1140) at K and CAL, Arnott (1838) thought that this was probably a mistake due to "the petal appearing ciliated with scattered longish hairs or bristles round the whole margin". Based on our observations, the flower in Roxburgh's drawing is correctly depicted except that the marginal hairs are perhaps too long. By contrast, in C. zippeliana there are no visible lateral marginal hairs on the petals. Using a scanning electron microscope, only a few loosely arranged extremely short hairs (less than $50 \mu \mathrm{m}$ ) have been observed (Sheue 2003).

Except for the genus Bruguiera, all flowers of the Rhizophoraceae are enclosed in a bracteole, two flowers with their own 


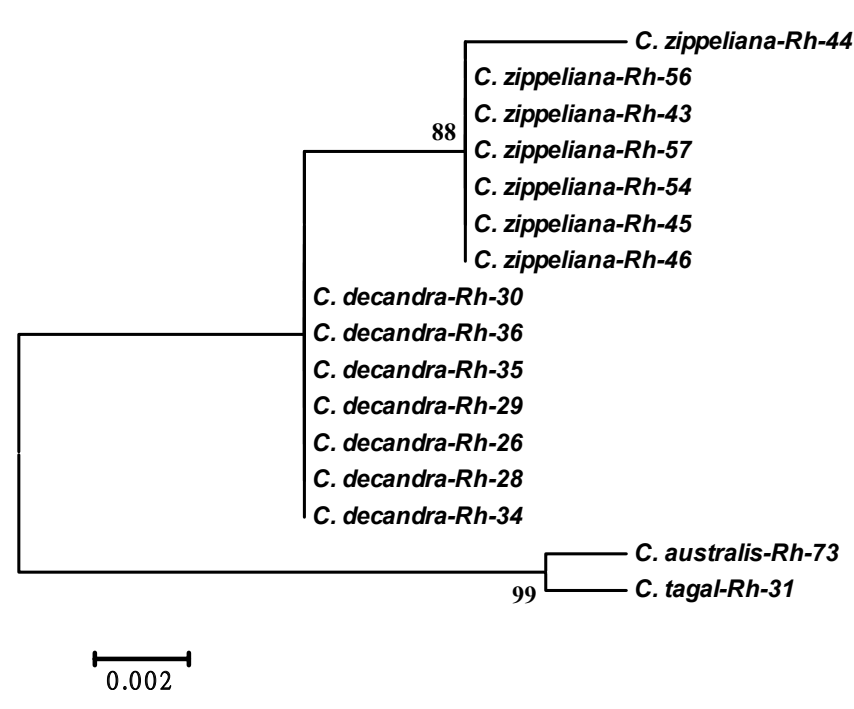

Fig. 6 The neighbour-joining tree of the seven accessions of both Ceriops decandra and C. zippeliana plus the two outgroups derived from the $t r n \mathrm{~L}$ intron sequence. Bootstrap values $>50 \%$ are shown on each branch.

bracteoles are again surrounded by a bract, and a certain number of such replicates constitute a compound bifurcate cyme-like inflorescence (Sheue 2003, Naskar \& Mandal 1999). The difference in inflorescence morphology for the two compared species in this study is distinct. Ceriops zippeliana has a simple head-like structure with a single layer of (primary) bracts enclosing 3-5 flowers, while that of $C$. decandra is dense, bifurcate, cyme-like, with multilayered (primary to fourth) bracts enclosing 6-10 or more flowers. The bifurcate cymelike inflorescence of $C$. decandra is actually similar to that of C. tagal, but the pedicels of the former are absent and lead to a "head-like cyme" (Sheue 2003). However, due to the obscure arrangement of the small sized bracts, this difference is not easily recognized, especially for desiccated specimens.

Leaf shape and stipule length provide additional information for identification. In addition, the colleters at the adaxial base of the stipule of Ceriops could serve as a diagnostic character in the field with the help of hand lens $(10 \times)$, as Sheue et al. (2003, 2005) reported for the species of Kandelia and Bruguiera. But it should be mentioned that only fully expanded stipules (before dropping off the stem) can be used for comparison.

While flowering, the flowers of $C$. zippeliana only open slightly with the erect and reflex apex of calyx lobes pointing towards the floral axis. In contrast, the flowers of $C$. decandra are partially patent with oblique calyx lobes. There are marked differences in pollen grain characters, such as size and surface ornamentation. Pollen size is less in $C$. zippeliana $(15.43 \pm 1.16 \mu \mathrm{m})$ than in $C$. decandra $(21.0 \pm 1.49 \mu \mathrm{m})$, and surface ornamentation in the former is here confirmed to be the rugulate-type, while in the latter it is the scabrate-type (Das \& Ghose 1990).

The ovoid fruit of Ceriops has persistent calyx tubes and lobes and their detailed and distinct surface ornamental patterns are useful for interspecific differentiation (Sheue 2003). Ceriops decandra has dome-like calyx tubes, while C. zippeliana has shallow disc-like calyx tubes. The calyx lobes of $C$. zippeliana are very short and erect when compared to the relative longer and ascending calyx lobes of $C$. decandra. It is interesting, especially for the dispersal ecology, that the hypocotyl orientation of the two species ranges from erect, to ascending or descending in both species (Sheue 2003), while those of the other species of the Rhizophoraceae are descending.

Tan et al. (2005) studied the genetic structure of ten populations from the Malay Peninsula and North Australia of the so-called C. decandra using the inter-simple sequence repeat (ISSR). They concluded that the populations could be grouped into three major geographic regions, i.e., West coast of West Malaya, Southwest Malaya (including Singapore) and East Malaya, and North Australia. The populations they sampled from Southwest Malaya (including Singapore) and East Malaya are probably C. zippeliana. A similar genetic discontinuity between the Asiatic populations of Ceriops was observed in this study as well using the chloroplast $t r n \mathrm{~L}$ intron. Three stable indels and two stable transversions and the phylogenetic tree derived from these data also support the idea that $C$. zippeliana can be separated as a distinct species from C. decandra.

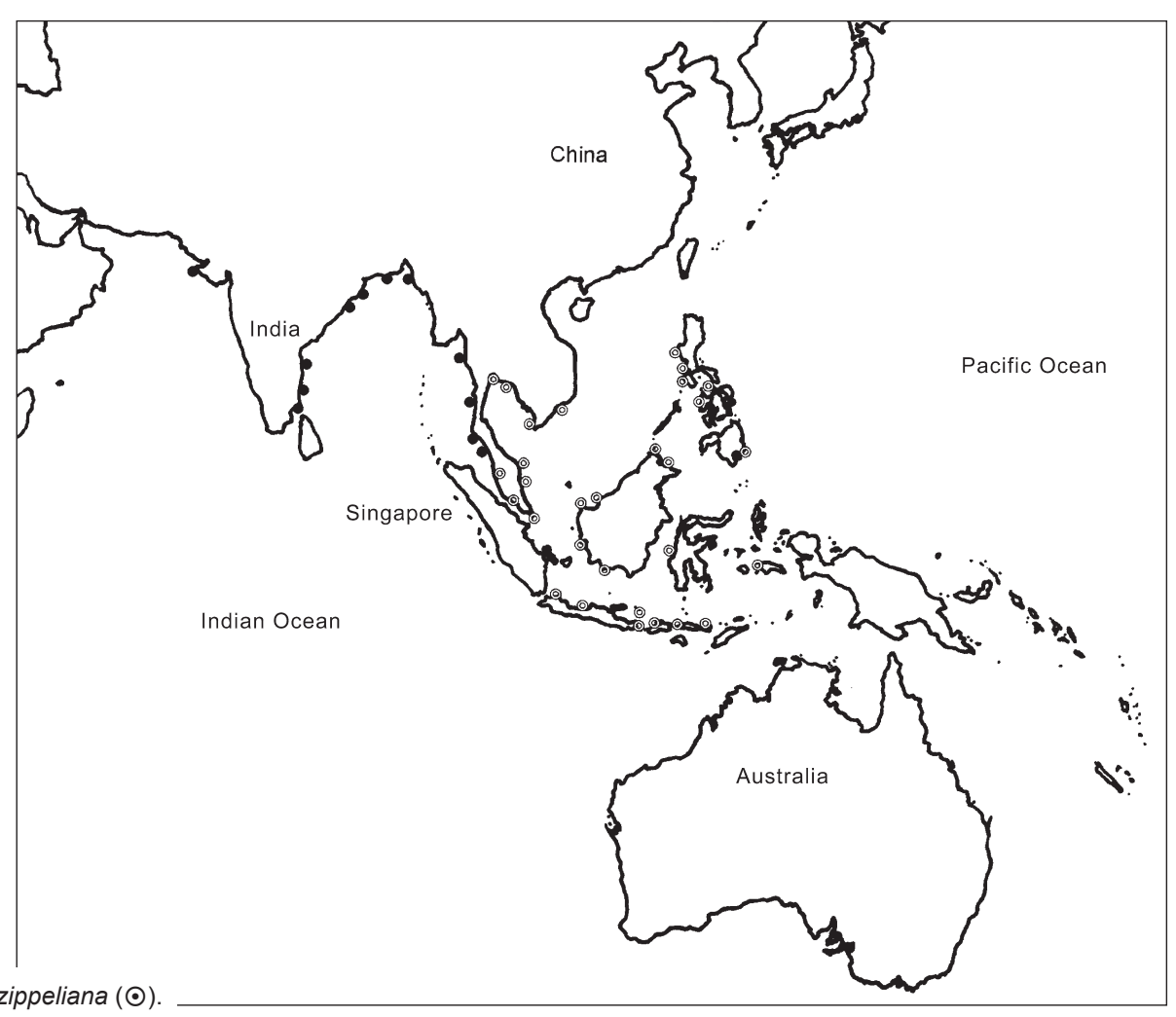

Fig. 7 Localities of Ceriops decandra $(\bullet)$ and C. zippeliana (๑) 
We find that $C$. zippeliana is found throughout a large part of Malesia. Hou (1958) reports that C. zippeliana was not found in Sumatra and the Lesser Sunda Islands. However, we have examined specimens of $C$. zippeliana collected from the Lesser Sunda Islands, such as Bali and Lombok Island, and our findings are confirmed by a local mangrove handbook (Kitamura et al. 2004) which shows the photographs of C. zippeliana (labelled as $C$. decandra) in this region. Based on our field observations, the northern boundary of $C$. zippeliana may be located in Malacca, West Malaysia. According to the herbarium specimens examined, Satun, a small province in the south of Thailand that borders Malaysia, is the southern boundary of C. decandra at the West coast of the Malay Peninsula. Nevertheless, more research, especially extensive field survey, is still needed to elucidate the population boundaries of $C$. decandra and C. zippeliana in the Malay Peninsula.

Further ongoing taxonomic work pertaining to Ceriops is in progress in order to clarify the species number and the phytogeographic range of each taxon.

Acknowledgements The authors thank M. Roos and P. Hovenkamp for providing valuable suggestions for the manuscript, P. Saenger and S. Das for improving the manuscript, S.K. Lee (Singapore), K.H. Lo and R. Kiew (Malaysia) for helping us with the collection of materials; S.H. Yen for help in copying the references in the UK, the National Parks Board in Singapore for granting access to field sites and logistic support; C.K. Liao for line drawings of the specimens; and the following herbaria for permission to study and/or loans of specimens, BM, BO, CAL, DNA, GH, HAST, IBSC, K, L, MO, PPI, SING, SINU and TAI. This study was supported by the National Science Council (NSC94-2311-B-020-001-) and the National Chiayi University (NCYU 96T001-02-06-019) of Taiwan.

\section{REFERENCES}

Arnott W. 1838. On the Rhizophoraceae. Annals of Natural History 1: $359-374$.

Banerjee LK, Sastry ARK, Nayar MP. 1989. Mangroves in India, identification manual. Botanical Survey of India, Government of India, Calcutta.

Blume CL. 1849. Museum Botanicum Lugduno-Batavum sive stirpium Exoticarum, Novarum vel Minus Cognitarum ex Vivis aut Siccis Brevis Expositio et Descriptio: 126-131.

Das S, Ghose M. 1990. Pollen morphology of some mangrove plants of Sunderbans, West Bengal. Journal of the National Botanical Society (India) 44: 59-75.

Doyle JJ, Doyle JL. 1987. A rapid DNA isolation procedure for small quantities of fresh leaf tissue. Phytochemistry Bulletin 19: 11-15.

Duke NC. 2006. Australia's mangroves: the authoritative guide to Australia's mangrove plants. University of Queensland, Queensland.

Felsenstein J. 1985. Confidence limits on phylogenies: an approach using the bootstrap. Evolution 39: 783-791.

Field CD. 1995. Journey amongst mangroves. International Society for Mangrove Ecosystems, Okinawa, Japan.

Griffith W. 1835. On the family of Rhizophoraceae. Transactions of the Medical and Physical Society of Calcutta 8: 1-12.

Hall TA. 1999. BioEdit: a user-friendly biological sequence alignment editor and analysis program for Windows 95/98/NT. Nucleic Acid Symposium Series 41: 95-98.

Hillis DM, Bull JJ. 1993. An empirical test of bootstrapping as a method for assessing confidence in phylogenetic analysis. Systematic Biology 42 : $182-192$.

Hogarth PJ. 2007. The biology of mangroves and seagrasses. 2nd ed. Oxford University Press, Oxford, UK

Hou D. 1958. Rhizophoraceae. Flora Malesiana, Ser. I, Vol. 5: 429-473.

Kimura M. 1980. A simple method for estimating evolutionary rates of base substitution through comparative studies of nucleotide sequences. Journal of Molecular Evolution 16: 111-120.

Kitamura S, Anwar C, Chaniago A, Baba S. 2004. Handbook of mangroves in Indonesia, Bali, Lombok. Jaya Abadi, Denpasar, Bali.

Kumar S, Tamura K, Jakobsen IB, Nei M. 2001. MEGA 2.1: Molecular evolutionary genetics analysis software. Arizona State University, Tempe, AZ.
Lin P. 1999. Mangrove ecosystem in China. Science Press, Beijing, China. Naskar K, Mandal R. 1999. Ecology and biodiversity of Indian mangroves. Daya Publishing House, Delhi.

Roxburgh W. 1814. Hortus Bengalensis. Mission Press, Serampore.

Saenger P. 2002. Mangrove ecology, silviculture and conservation. Kluwer Academic Publishers, The Netherlands.

Saitou N, Nei M. 1987. The neighbor-joining method: a new method for reconstructing phylogenetic trees. Molecular Biology and Evolution 4: 406-425.

Sheue CR. 2003. Comparative morphology and anatomy of the eastern mangrove Rhizophoraceae. Unpublished D.Phil. thesis, National Sun Yatsen University, Kaohsiung, Taiwan.

Sheue CR, Liu HY, Yong JWH. 2003. Kandelia obovata (Rhizophoraceae), a new mangrove species from Eastern Asia. Taxon 52: 287-294.

Sheue CR, Yong JWH, Yang YP. 2005. The Bruguiera (Rhizophoraceae) species in the mangroves of Singapore. Taiwania 50: 251-260.

Taberlet P, Gielly L, Pautou G, Bouvet J. 1991. Universal primers for amplification of three non-coding regions of chloroplast DNA. Plant Molecular Biology 17: 1105-1109.

Tan F, Huang Y, Ge X, Su G, Ni X, Shi S. 2005. Population genetic structure and conservation implications of Ceriops decandra in Malay Peninsula and North Australia. Aquatic Botany 81: 175-188.

Tomlinson PB. 1986. The botany of mangroves. Cambridge University Press, Cambridge.

Tsai CC, Huang SC, Chou CH. 2006. Molecular phylogeny of Phalaenopsis Blume (Orchidaceae) based on the internal transcribed spacers 1 and 2 of nuclear ribosomal DNA. Plant Systematics and Evolution 256: 1-16.

\section{IDENTIFICATION LIST}

\section{Specimens examined of Ceriops decandra:}

Anonymous s.n. (1811) (K) - Battic 20469 (K); Bhowmik $5(\mathrm{~K})$ - Clarke 21585, 35791 (BM), $21647 \mathrm{~A}(\mathrm{~K})$; Chaffey 3, $4(\mathrm{~K})$; Congdon $152(\mathrm{GH})$; Congdon \& Hamilton $258(\mathrm{GH})$ - Fukuoka \& Ito T-35621, T-35809 (L) - Gamble 17675 (CAL); Griffith s.n. (1844) (K), 86, 209 (L), 477 (BM), 2209 (K) - Haines 4135 (CAL, K); Heinig s.n. (1894) (L), s.n. (1890) (BM), 23 (GH), 233 (CAL); Hooker \& Thomson s.n. (no date) (K) - Kerr 13960, 16547, 17300, 18594 (BM, K); Khan 296 (CAL) - Matthew 12755 (CAL); Matthew \& Paramasivan s.n. (1979) (GH), 23755 (CAL, K); Mokim s.n. (1898) (BM, GH), 169 (CAL); Mooney 3353, $3383(\mathrm{GH}, \mathrm{K}), 3354(\mathrm{GH})$; Morisson 360 (CAL); Mukerjee 4503, 4762, 5346 (CAL) - Parker 2197, 2206 (GH); Pauigrahi 23428, 23928 (CAL); Perumal 17945, 17947, 18061 (CAL) - Ramamurthy 86440 (CAL); Rao 2260, 5656 (CAL); Rogers 438 (CAL) - Sandom 63 (K); Sheue M32-34, M80-85 (CHIA) - Thomson s.n. (no date) (L) - Ubolchalaket $334(\mathrm{~K})$ - Venugopal 22699, 22703 (CAL) - Wallich 78 (BM), 4875 (CAL), 4875a (K), 4875c, 4875d (CAL); Wight $995(\mathrm{GH})$.

Specimens examined of Ceriops zippeliana:

Ahern 71 (MO); Ahmad 54759 (BO); Angeles s.n. (1916) (MO), s.n. (1917) (GH), 26499 (IBSC) - Backer 2233, 27650, 27844, 34931, 39931 (BO); Barbon et al. $18895(\mathrm{GH})$; Borden 2354 (L); Boschproefstation bb15569 (K, L) - Castro \& Melegrito s.n. (1923) (GH); Chai et al. S30659 (GH); Conklin 729 (GH); Cortes \& Knapp s.n. (1915) (GH) - De Leon s.n. (1913) (BM); Dolman 6626 (SING) - Elmer 2457 (L), 12027 (BM, BO, GH, MO), 20030 (BM, CAL, MO), 20031 (BM) - Frodin \& Ismawi 2007 (GH, MO) - Galatira s.n. (1949) (GH, TAI) - Hoogerwerf 2 (BO); Hou 137 (K), 746 (BO, GH), 747 (K) - Ismail S-14 (SING) - Kerr s.n. (1920, 1924) (BM), 2126 (BM, K); Keßler et al. PK1654 (K); Kitamura s.n. (1995) (BO); Koch 256 (BO); Kochummen 7730 (SING); Koorders 21663 (CAL, K) - Lai LJ58, LJ126 (SING); Loher 2196, 2197 (CAL), 13767 (GH); Lowell 2735 (GH) - Marcan 1365 (BM); Maxwell 93-156, 93-853 (GH); Meijer 1320 (SING); Merrill 1047 (GH); Merritt 9850 (MO); Meyer 2313 (BO, L), Miranda s.n. (1912) (BM); Murata et al. J494 (L, MO) - Neth. Ind. For. Service bb16712 (GH) - Pelenkakae s.n. (1896) (BO); Pierre $1(\mathrm{~K})$; Pollane $853(\mathrm{~K})$ - Reilingh 6583 (BO); Rintjak 1618 (BO); Romero \& Chavenz PPI29092 (K); Romero \& Majaducon 29563 (GH) - Schmutz 1618, 2510 (BO), 2778, 3014 (BO, L); Shah MS868 (L, SING); Shah \& Noor MS809 (GH, SING), MS810 (BO); Sheue M336-337(CHIA); Sider 13120 (MO); Sulit 4945, $5200(\mathrm{GH})$; Sun 9108 (BO) - Tang \& Sidek 302 (SING); Teijsmann s.n. (1896), 3071, 13790 (BO) - Van Leeuwen-Reijnvaan 7877 (BO); Verheijen 2909, 4192, 4513 (L); Vidal $756(\mathrm{GH})$; Vorderman s.n. (no date) (BO) - Wenzel 1446 (BM, $\mathrm{GH}, \mathrm{MO})$ - Zollinger 2735 (BM). 